\title{
An explosion of leaf growth after stress conditions
}

\author{
A. Kleinendorst \\ Institute for Biological and Chemical Research on Field Crops and Herbage (IBS), \\ Wageningen, the Netherlands
}

Accepted: 13 February 1975

\section{Summary}

When leaf growth in maize plants under stress conditions is inhibited due to greater retardation in cell elongation than in cell division, temporarily accelerated leaf growth will occur after discontinuing the stress conditions.

\section{Introduction}

Earlier investigations have shown that local treatment at low temperature gave retardation or complete inhibition of leaf growth in maize plants. The cause of this reduction was found to be dependent on the region treated (Kleinendorst \& Brouwer, 1970; 1972).

At a low root temperature water shortage will occur, causing retardation in cell elongation. At a locally low temperature above the meristematic region, the carbohydrate transport to this region is temporarily restricted, reducing cell elongation. A low temperature of the meristem will affect the biochemical processes in this region, inhibiting cell elongation and cell division.

A decrease in cell elongation affects leaf growth directly, whereas a decrease in cell division can only be observed after a longer period. When a decrease in leaf growth due to locally applied low temperature is discontinued by raising the temperature the growth pattern afterwards will probably be considerably influenced by the cause of the preceding retardation, viz caused by an inhibition of either cell elongation only, or cell division only, or both.

\section{Materials and methods}

Maize seedlings (variety 'Pioneer 395 ') were grown on Hoagland solution in a climate room at $20^{\circ} \mathrm{C}$ under an 18-h light period per $24 \mathrm{~h}$ and a light intensity of about $70 \mathrm{~W} \mathrm{~m}^{-2}$. At the 8th leaf stage (8th leaf just emerging from the surrounding sheaths) the plants were transferred to the experiment room, where root temperature, meristem temperature and the temperature locally above the meristem could be varied independently. The culture solution was aerated. Leaf extension was continuously measured and recorded (Kleinendorst \& Brouwer, 1970; 1972). 


\section{A. KLEINENDORST}

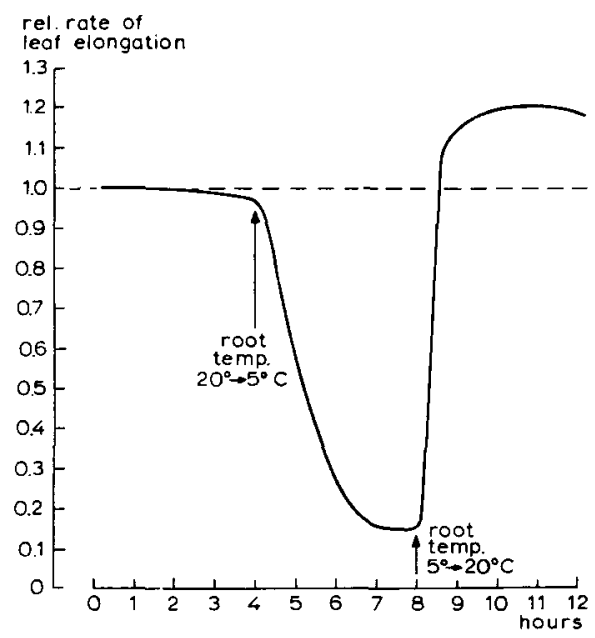

Fig. 1. Changes in the rate of leaf elongation that occurred when the root temperature was changed from 20 to $5{ }^{\circ} \mathrm{C}$ and from 5 to $20^{\circ} \mathrm{C}$.

\section{Results and discussion}

Earlier investigations have shown that after lowering the root temperature inhibition of leaf growth will occur, after which a gradual adjustment will take place in leaf growth and water content. For this reason, in this experiment a root temperature of $5{ }^{\circ} \mathrm{C}$ was only applied for a few hours and then raised again to $20^{\circ} \mathrm{C}$, just before adaptation had occurred. Fig. 1 shows that after raising the temperature to $20{ }^{\circ} \mathrm{C}$, leaf growth rapidly increases immediately and attains a growth rate that is almost $20 \%$ higher than that of the control. When the meristem temperature is temporarily lowered, no increased leaf growth will occur (Fig. 2) after raising the temperature again. As was shown in earlier investigations the inhibitions in leaf growth occurring at decreasing root or meristem temperature are due to two dif-

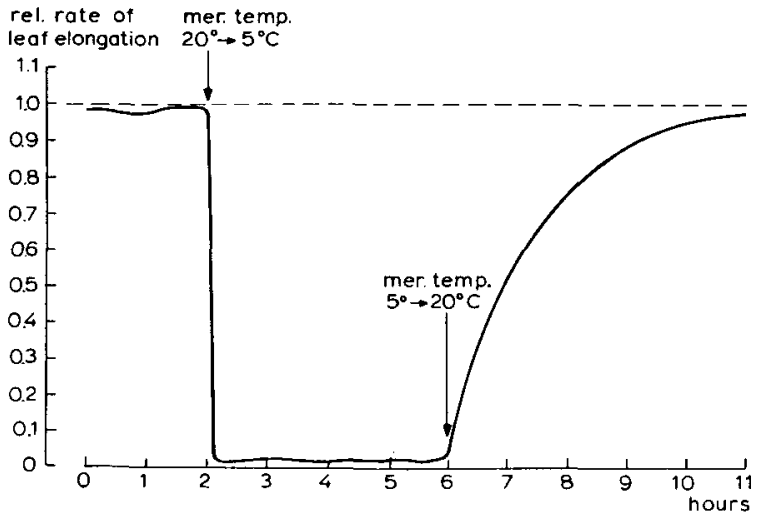

140
Fig. 2. Changes in the rate of leaf elongation that occurred when the meristem temperature was changed from 20 to $5^{\circ} \mathrm{C}$ and from 5 to $20^{\circ} \mathrm{C}$.

Neth. J. agric. Sci. 23 (1975) 
ferent processes. At a low root temperature water shortage occurs and cell elongation is much decreased, causing leaf growth to terminate. Cell division, however, continues as usual or is retarded to a much less extent. At low meristem temperature inhibition is due to a decrease in the biochemical processes in the meristematic region, reducing cell elongation as well as cell division. Therefore, immediate inhibition of leaf growth occurs (Fig. 2) when the meristem temperature is decreased from $20^{\circ} \mathrm{C}$ to $5{ }^{\circ} \mathrm{C}$. Cell elongation and cell division are directly affected. When the temperature is increased again, cell elongation and cell division will gradually start again.

At low root temperature (Fig. 1) growth decreases slowly and the water present is used in cell elongation. When root temperature is raised to $20^{\circ} \mathrm{C}$, a growth explosion occurs immediately. During the low root temperature cell elongation could not take place due to water shortage, so the number of non-elongated cells in the meristematic region increased. When the root temperature is raised now, the plant can take up water again immediately, resulting in a great number of non-elongated cells starting to elongate. This may possibly apply to every temporary water shortage. Generally, cell division is less affected by water shortage than cell elongation (Brouwer, 1962; Slatyer, 1967).

If plants are locally cooled to $5{ }^{\circ} \mathrm{C}$ above the meristematic region for e.g. 1 day, after which the temperature is again raised, a considerable growth explosion will occur, during a short period (Fig. 3). In this case local cooling above the meristematic region will induce inhibition of the carbohydrate transport to the meriste-

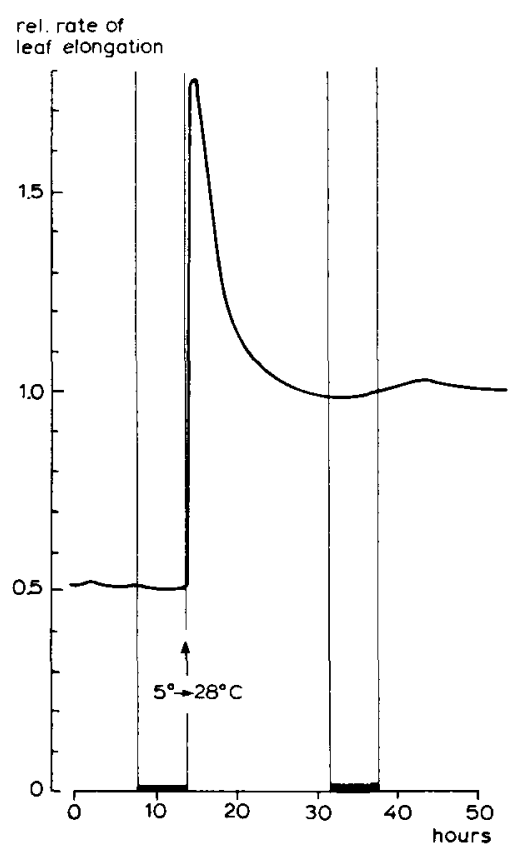

Fig. 3. Changes in the rate of leaf elongation that occurred when the temperature locally above the meristem was increased from 5 to $28^{\circ} \mathrm{C}$. 

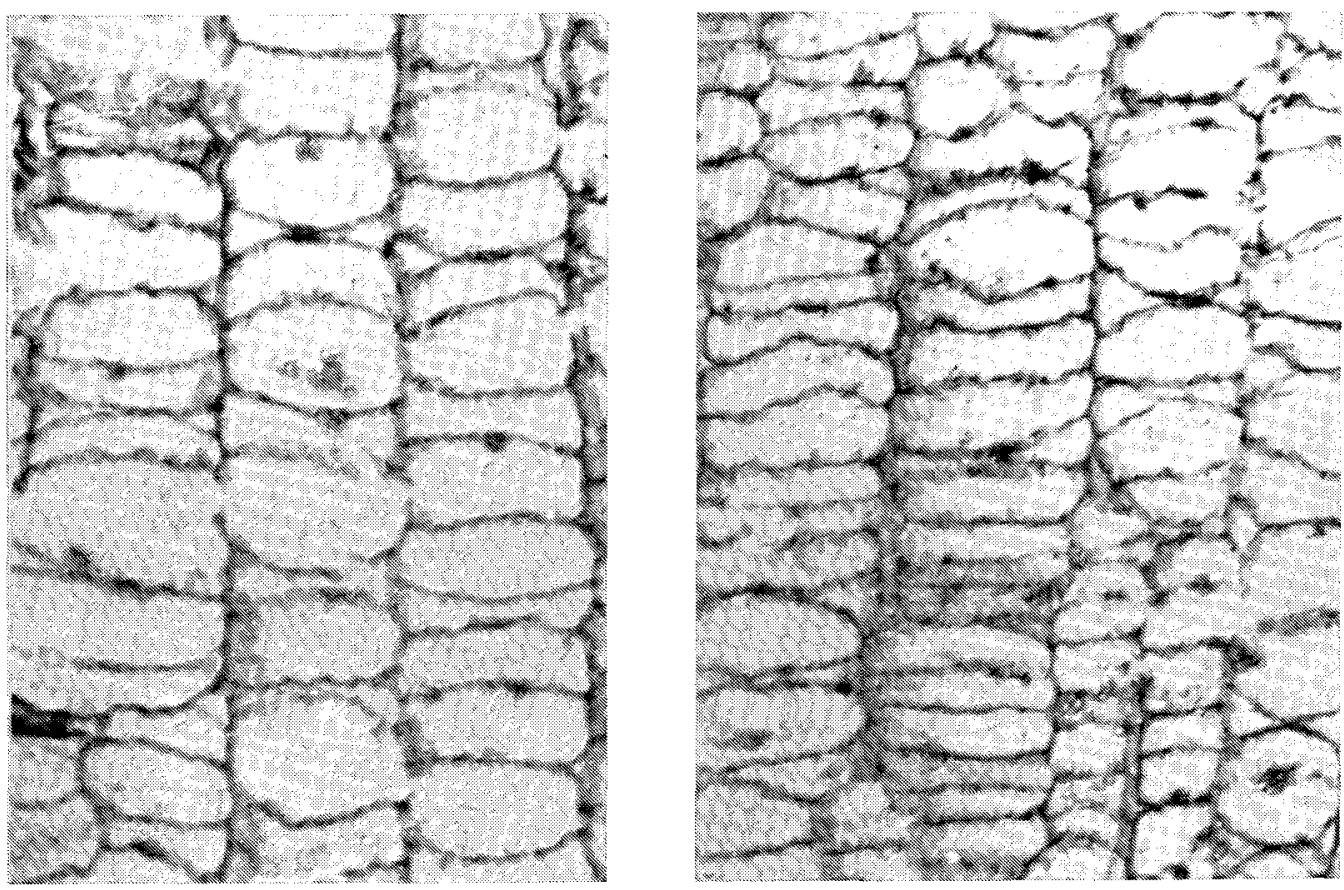

Fig. 4. Cell pattern about $1 / 2 \mathrm{~cm}$ above the meristematic region. Left: control. Right: plants treated at low temperature locally above the meristem.

matic region (Kleinendorst \& Brouwer, 1972), which will also retard cell elongation. Cell division is less affected by this, and so a greater number of non-elongated cells may be present at continuing cell division. When the temperature in the region is increased again, considerable amounts of carbohydrates will be available due to the restored transport of accumulated carbohydrates to the meristem. The growth explosion could be caused by this, since a great number of non-developed cells will start elongating. Cell countings just above the meristematic region showed that the control plants contained at least $20 \%$ fewer cells per surface unit than the treated plants (Fig. 4).

A similar short growth explosion was also observed after a short period of drought. When water was again available a temporary growth acceleration occurred compared to the plants which were given a regular supply of water (Gates, 1955; Slatyer, 1967). Barlow \& Boersma (1972) also found that when the soil water suction after $12 \mathrm{~h}$ was lowered from 300 to $30 \mathrm{kPa}^{1}$ a temporary growth acceleration occurred. They, however, consider this to be due to an accumulation of cell metabolites during the stress conditions. Boyer (1970) demonstrated that an ap-

$11 \mathrm{kPa}=1000 \mathrm{~Pa}=10^{-2}$ bar. $\mathrm{Pa}$ (pascal) is the recommended SI unit for pressure; $1 \mathrm{~Pa}=$ $1 \mathrm{~N}$ (newton) $\mathrm{m}^{-2}$. 


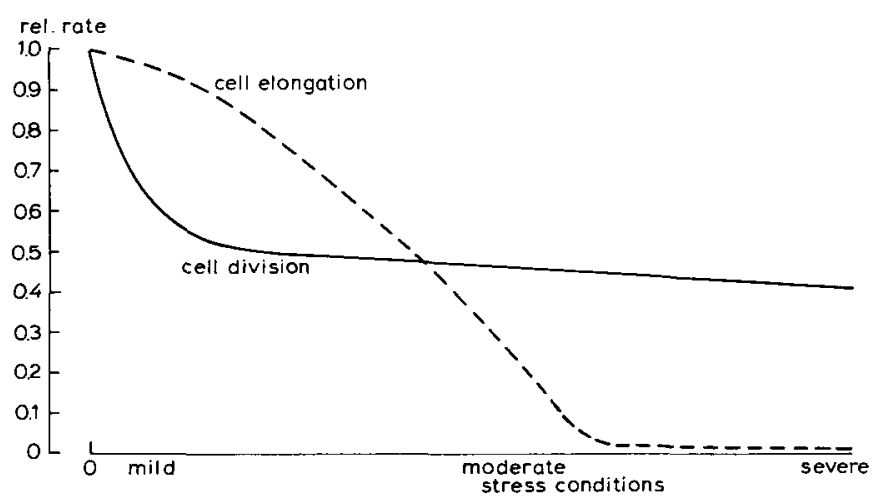

Fig. 5. Model of the relative rate of cell elongation and cell division under increasing stress conditions.

preciable reduction of cell elongation caused by low leaf water potentials only brought about a slight reduction in the photosynthesis, resulting in an accumulation of carbohydrates during this slight moisture stress. Green (1968) assumes that such an accumulation gives an increase in the plasticity of the cell wall.

On the contrary, however Nieman \& Poulsen (1962) have demonstrated by cell countings that an increase in DNA content is linearly related to an increase in the number of cells. Stress conditions reduce the DNA content. Gardner \& Nieman (1964) demonstrated that in cut cotyledons of radish seedlings the rate of increase in DNA content was reduced to about $60 \%$ when the leaf water potential was decreased from 0 to $-200 \mathrm{kPa}$. However, when desication continues to -1600 $\mathrm{kPa}$ the rate of increase in the DNA content was no longer affected. According to Slatyer (1967) the rate of water shortage might have a different effect, reducing cell division more or less heavily than cell elongation.

In view of the preceding, with each growth retardation in which cell division is not reduced or to a less extent than cell elongation, it would be theoretically possible that temporarily accelerated leaf growth may occur after eliminating the retardation.

All the different results given by the authors mentioned above can be brought in accordance by assuming a relation (theoretically) between cell elongation and cell division on one hand and water stress on the other hand as given in Fig. 5 . In Fig. 5 it is assumed that under slight stress conditions cell division is more inhibited than cell elongation. Under increasing stress conditions cell division will hardly continue to decrease, whereas the decrease in cell elongation does. While cell elongation is completely blocked, reduced cell division will continue, which may explain the leaf growth explosion mentioned in this paper.

\section{Acknowledgments}

The author is indepted to miss H. W. Luiks for the microscopic work and to miss A. H. van Rossem for translating the manuscript. 


\section{A. KLEINENDORST}

\section{References}

Barlow, E. W. R. \& L. Boersma, 1972. Growth response of corn to changes in root temperature and soil water suction measured with an L.V.D.T. Crop Sci. 12: 251-252.

Boyer, J. S., 1970. Leaf enlargement and metabolic rates in corn, soybean and sunflower at various leaf water potentials. Pl. Physiol. 46: 233-235.

Brouwer, R., 1962. Influence of temperature of the root medium on the growth of seedlings of various crop plants. Jaarb. Inst. biol. scheik. Onderz. LandbGewass. 1962: 11-18.

Gardner, W. R. \& R. H. Nieman, 1964. Lower limit of water availability to plants. Science 143 (3613): 1460-1462.

Gates, C. T., 1955. The response of young tomato plants to a brief period of water shortage. I. The whole plant and its principal parts. Aust. J. biol. Sci. 8: 196-214.

Green, P. B., 1968. Growth physics in Nitella: a method for continuous in vivo analysis of extensibility based on a micromanometer technique for turgor pressure. Pl. Physiol. 43: 1169-1184.

Kleinendorst, A. \& R. Brouwer, 1970. The effect of temperature of the root medium and of the growing point of the shoot on growth, water content and sugar content of maize leaves. Neth. J. agric. Sci. 18: 140-148.

Kleinendorst, A. \& R. Brouwer, 1972. The effect of local cooling on growth and water content of plants. Neth. J. agric. Sci. 20: 203-217.

Nieman, R. H. \& L. L. Poulsen, 1962. The light dependence of nucleic acid and protein synthesis by isolated radish cotyledonary leaves. Pl. Physiol. 37 (suppl.): 21-22.

Slatyer, R. O., 1967. Plant-water relationships. Academic Press. London/New York. 